\title{
Некоторые проблемы кашмирской диалектологии
}

\begin{abstract}
В статье исследуются генетические отношения литературного кашмири и четырех диалектов, распространенных за пределами Кашмирской долины. В прошлом эти диалекты нередко классифицировались как кашмирские, однако аргументы в пользу такой классификации зачастую были неубедительны. Автор статьи приходит к выводу, что 2 диалекта - сираджи и рамбани - не являются не только кашмирскими, но и дардскими, а относятся к индоарийской группе. В то же время 2 других диалекта погули и каштавари - действительно обнаруживают большую генетическую близость к стандартному кашмири.

Ключевые слова: кашмири, дардские языки, индоарийские языки, генетическая классификация, диалектология.
\end{abstract}

\section{1. Вводные замечания}

Вплоть до недавнего времени диалекты языка кашмири привлекали внимание главным образом социолингвистов. Поэтому собственно лингвистическое их изучение заметно отстает от социолингвистического ${ }^{1}$, а сравнительно-историческое - лишь делает первые шаги. Тем не менее, даже та общая картина, которая вырисовывается при современном уровне знаний, чрезвычайно интересна. Прежде всего, обращает на себя внимание несомненное и разительное несходство ситуации в самой Кашмирской долине и в горных районах, примыкающих к ней с юга, где также предполагается наличие кашмирских диалектов.

В Кашмирской долине обычно выделяют три диалектные области: Камраз (север и северо-запад), Мараз (юг и юго-восток) и район г. Сринагара, иногда называемый Ямраз [Коган 2009; Kaul 1995]. Распространенные в этих областях говоры кашмири (называемые соответственно камрази, марази и ямрази²) весьма близки друг к другу и взаимопонимаемы [Kaul 1995]. Выявленные на сегодняшний день расхождения между ними следующие:

1) сохранение в марази церебрального $r$ при переходе его в $r$ в остальных диалектах;

2) образование в марази причастия настоящего времени при помощи суффикса -an, при том, что в остальных диалектах данный суффикс имеет вид -ān;

3) наличие в диалекте камрази ряда характерных особенностей просодии, нехарактерных для других диалектов;

4) наличие в каждом из диалектов некоторого количества специфических лексических единиц [ibid.].

Непосредственно к югу от собственно Кашмира, в Западных Гималаях распространены четыре идиома - каштавари, погули, сираджи и рамбани, нередко (хотя и не всегда) причисляемые исследователями к кашмирским диалектам. Они обнаруживают

${ }^{1}$ В этой связи уместно привести следующее высказывание О. Кауля: «There has been no serious linguistically oriented dialect research on Kashmiri» [Kaul 1995, 304].

2 Диалект ямрази лежит в основе литературного языка, называемого также «стандартный кашмири».

Journal of Language Relationship • Вопросы языкового родства • 7 (2012) • Рp. 47-70 • ㄷ Коган А. И., 2012 
весьма существенные материальные отличия друг от друга и от диалектов Кашмирской долины. Это обстоятельство заставляло и заставляет часть ученых сомневаться в правомерности классификации данных идиомов как диалектов кашмири, а иногда и ставить под вопрос их принадлежность к дардской группе. На сегодняшний день следует говорить даже не о проблеме, а о целой группе проблем, связанных с определением места указанных диалектов внутри арийской языковой общности и их отношений с языком кашмири. В нижеследующих подразделах мы остановимся на наиболее интересных и важных из этих проблем.

\section{2. О генетической характеристике «смешанных» диалектов языка кашмири}

Кашмири является в ареальном отношении самым южным языком дардской группы. Следствием такого географического положения явилось глубокое и разностороннее влияние, оказанное и оказываемое на данный язык индоарийскими языками‥ Хотя сам факт этого влияния является общепризнанным, его степень и последствия все еще остаются в целом ряде аспектов неизученными. При этом целый ряд проблем, все еще ждущих своего решения, был поставлен исследователями почти столетие назад. Пожалуй, самой интересной из них является проблема, связанная с так называемыми «смешанными диалектами» - идиомами с неясным генетическим положением, распространенными на границе дардского и индоарийского языковых ареалов.

В своем фундаментальном труде "Linguistic Survey of India" Дж. Грирсон предложил рассматривать диалекты сираджи и рамбани, распространенные в Западных Гималаях к югу от Кашмирской долины ${ }^{4}$, в качестве смешанных, допустив возможность их отнесения как к диалектам кашмири, так и к диалектам прилегающих с юга индоарийских языков. Согласно этой точке зрения, сираджи следует считать «смесью» кашмири и некоего языка группы пахари, а рамбани - «смесью» сираджи и догри [Grierson 1919, $433,458]$. В некоторых более поздних исследованиях генетическая принадлежность данных диалектов рассматривается иначе. Так, Д. И. Эдельман считает их диалектами кашмири, подвергшимися сильному индоарийскому влиянию [Edelman 1983: 298]. Индийский ученый П. К. Коуль предпочитает относить сираджи к группе пахари [Koul 1977; 20061]. В своем грамматическом очерке он подробно рассматривает аргументы Дж. Грирсона в пользу причисления этого диалекта к числу кашмирских и показывает (в большинстве случаев вполне убедительно), что указанные Дж. Грирсоном изоглоссы в действительности объединяют сираджи не только с кашмири, но и с соседними диалектами группы пахари [Koul 20061: 319-321]. На близких позициях стоит норвежская исследовательница Рут Дайла Шмидт, считая, впрочем, возможным рассматривать сираджи как в качестве индоарийского языка группы пахари, так и как креольский язык [Schmidt 1981].

Подобный разнобой во мнениях, а также и некоторые из высказанных гипотез сами по себе, несомненно, свидетельствуют о все еще сохраняющейся неясности в вопросе о генетической принадлежности диалектов сираджи и рамбани. Оценивая приведенные здесь точки зрения, можно сказать, что предположение Д. И. Эдельман выглядит несравнимо более правдоподобным по сравнению с идеями Дж. Грирсона, фактически пытавшегося рассматривать данную проблему с позиций ныне полностью отвергнутой

${ }^{3}$ Об этом влиянии см., например [Grierson 1919; Коган 2011].

${ }^{4}$ Ныне в округе Джамму индийского штата Джамму и Кашмир. 
компаративистами теории «скрещения языков». Однако и гипотеза Д. И. Эдельман также требует проверки. Во всяком случае, нет оснований считать ошибочным и альтернативный взгляд, высказанный П. К. Коулем и Р. А. Шмидт, согласно которому сираджи индоарийский язык группы пахари. Отнесение же последнего к креольским языкам не представляется обоснованным. Насколько нам известно, ни одному исследователю не удалось выделить в диалекте сираджи каких-либо креольских черт. Кроме того, «креольская гипотеза» сама по себе вовсе не решает проблему отношения данного диалекта к языкам группы пахари и к кашмири, поскольку принятие ее автоматически заставляет поднять вопрос о языке-лексификаторе. До сих пор никаких точек зрения на этот счет высказано не было.

Поиски приемлемого решения проблемы «смешанных» диалектов существенно затрудняет крайний недостаток материала. По диалекту сираджи имеются лишь три относительно небольших грамматических очерка. Первый из них, опубликованный более столетия назад Т. Г. Бейли [Bailey 1903: 36-46], включает грамматические таблицы, два коротких текста, словник и краткий фразарий. Второй написан Дж. Грирсоном и включен во вторую часть VIII тома многотомного обзора языков Индии [Grierson 19192: 433 457]. В нем помимо нового материала используется также материал, собранный Т. Г. Бейли. Третий очерк опубликован П. К. Коулем на языке хинди в 1977 г. и переиздан в 2006 г. [Koul 19771; 20061]. На сегодняшний день это самое новое и, пожалуй, самое подробное описание диалекта сираджи. Кроме трех указанных публикаций, следует отметить также статью Р. А. Шмидт и В. К. Кауля, вышедшую в 2008 г. в журнале “Acta Orientalia" [Schmidt, Kaul 2008]. Эта статья содержит список слов сираджи, включающий 267 единиц. Материал по диалекту рамбани еще более скуден. Фактически единственным полноценным источником данных по нему является очерк Дж. Грирсона в “Linguistic Survey of India” [Grierson 19192: 458-487]. Имеется также очерк Т. Г. Бейли [Ваiley 1903: 46-50], крайне сжатый и не содержащий материалов, отсутствующих в работе Дж. Грирсона.

Принимая во внимание вышесказанное, следует признать, что потенциальные возможности прояснения вопроса о генетической принадлежности для двух рассматриваемых диалектов неодинаковы. Материал по сираджи при всей его бедности все же может оказаться достаточным для скрупулезного сравнительно-исторического исследования разных уровней языковой системы. Относительно же рамбани этого сказать нельзя. Крайняя скудость данных по этому диалекту в некоторых случаях, по-видимому, будет непреодолимым препятствием для их полноценной интерпретации в рамках стандартной компаративной процедуры ${ }^{5}$. Так, вероятнее всего, невозможным окажется составление стословного списка рамбани, что не только исключает применение лексикостатистического метода, но и существенно затрудняет установление регулярных звукосоответствий в исконных словах, поскольку список Сводеша, как известно, представляет собой

${ }^{5} \mathrm{C}$ сожалением следует констатировать, что данная ситуация едва ли когда-либо изменится к лучшему. По сообщениям исследователей, ведущих полевую работу на севере округа Джамму, жители селения Рамбан говорят в настоящее время на диалекте зундхари, очень близком к соседнему диалекту погули. Языка же или диалекта с названием рамбани в регионе не отмечено (cм. [Mock 2008] со ссылкой на устное сообщение П. Хука). Весьма вероятно, что диалект рамбани к настоящему времени полностью вышел из употребления. Данные переписей населения Индии четко показывают, что в Рамбане еще в первой половине XX века полным ходом шел процесс смены языка. Согласно этим данным, в 1911 г. на рамбани говорил 2171 чел. [Grierson 19192: 458], в то время как в 1941 г. - 1202 чел. [Warikoo 1996]. Нетрудно подсчитать, что при сохранении данной тенденции рамбани должен был полностью исчезнуть к концу 70-х годов минувшего века. 
очень хорошую выборку базисной лексики. При этом, однако, диалект рамбани обнаруживает несомненную материальную близость к сираджи, на что указывал еще Дж. Грирсон [Grierson 19192: 458]. Поэтому вопрос о генетических отношениях с соседними языками едва ли может решаться для рассматриваемых диалектов по-разному, и результат, полученный нами для сираджи, скорее всего, будет иметь силу и для рамбани. Тем не менее, материал последнего будет в дальнейшем привлекаться нами по мере возможности.

Необходимо отметить, что, несмотря на существенный недостаток данных, в настоящее время исследователь-компаративист обладает заметно большим объемом фактов, необходимых для решения проблемы диалектов сираджи и рамбани, чем это было в минувшем столетии. В последние годы был выявлен ряд историко-фонетических изоглосс, разделяющих дардские и индоарийские языки, по-видимому, еще на праязыковом уровне. Хотя на сегодняшний день, скорее всего, нельзя установить, как проявилась в сираджи и рамбани каждая из этих изоглосс, в некоторых случаях это все же представляется возможным. Могут быть рассмотрены, например, такие расхождения, как различное отражение древних (общеарийских и общеиндоиранских) кратких дифтонгов и звонких придыхательных смычных согласных. Даже тот небогатый материал по сираджи и рамбани, который имеется ныне в нашем распоряжении, позволяет сделать определенные выводы о «поведении» этих диалектов в обоих указанных аспектах.

Общеарийский краткий дифтонг *ai, сохранявшийся в протодардской фонологической системе, в кашмири (а также в ряде кохистанских языков) утратил второй компонент в неконечном положении и развился в краткий гласный $a$ [Коган 2005: 19-22]. В сираджи и рамбани он в той же позиции отразился в виде передних гласных $i$ и $\bar{e}$ (сир. $e k k$,

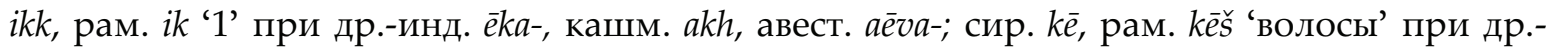
инд. kēśa-, авест. gaēsa- 'волос’7). Такая рефлексация, несомненно, предполагает стяжение дифтонга, аналогичное древнеиндийскому.

Наличие звонкой придыхательной серии уже отмечалось в ряде работ как яркая особенность сираджи и рабмани, отличающая их от собственно кашмири [Grierson 19192: 459; Edelman 1983: 298]. Сам по себе этот факт, впрочем, не может служить доказательством невозможности включения рассматриваемых диалектов в дардскую группу. В некоторых дардских языках, испытавших сильное индоарийское влияние, в частности, в торвали и кохистани долины Инда (майян), возникли вторичные звонкие придыхательные фонемы. Они обнаруживаются главным образом в заимствованиях, хотя известны и случаи их появления в исконной лексике в результате относительно поздних историко-фонетических процессов [Коган 2008] ${ }^{8}$. Вопрос о том, являются ли звонкие аспираты в сираджи и рамбани унаследованными от праязыкового состояния или же вторичными, до сих пор никем не ставился. Для его разрешения, на наш взгляд, необходимо ответить на два других вопроса: об отношении звонких придыхательных рамбани и сираджи к общеарийским и индоарийским и о наличии и (в случае наличия) происхождении примеров дезаспирации древних звонких придыхательных.

Как позволяет судить доступный языковой материал, звонкие придыхательные сираджи и рамбани в большинстве случаев соответствуют индоарийским звонким придыхательным. Это можно проиллюстрировать следующими примерами: сир., рам. bhō-

\footnotetext{
${ }^{6}$ О них см. [Коган 2005: 19-143].

7 Кашм. kīh ‘волосок' - индоарийское заимствование [Коган 2011].

8 Аналогичная картина обнаруживается и в некоторых иранских языках, например, в восточных диалектах белуджского.
} 
'становиться’ при др.-инд. bhavati 'есть, является, становится'; сир., рам. bhar- 'наполнять' при др.-инд. bharita- 'полный, накормленный', пали bharita- 'наполненный'9; сир. bhāndō 'горшок' при др.-инд. bhānda- то же; сир. bhrā, brhā, рам. brhā ‘брат' при др.-инд. bhrātar- то же; сир. bhrammū 'брови' при др.-инд. bhrū- 'бровь'; рам. dhām 'пир, угощение' при зап. пах. (джаунсари, пангвали) dhām то же < др.-инд. dhārma- 'относящийся к дхарме, спра-

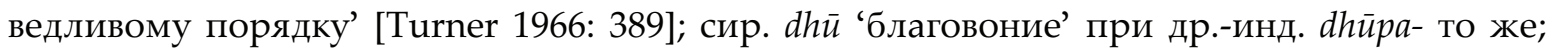
adho 'половина' при др.-инд. ardha- то же; bandh- 'связывать, завязывать' при др.-инд. bandhati 'связывает, завязывает'; duddh 'молоко' при др.-инд. dugdha- то же; рам. ubhu 'вверх’ при др.-инд. ürdhva- 'поднятый, находящийся наверху'; сир., рам. ghar 'дом' при пали ghara- то же; сир. ghaš- 'тереть' при др.-инд. gharșati ‘трет’; сир. ghās 'трава, сено' при др.-инд. ghāsa- 'пища; трава на пастбище'; ghiũ 'топленое масло' при др.-инд. ghrta- то же; langh- 'проходить' при др.-инд. langhayati- 'переходит, перепрыгивает', синдхи langhanu 'проходить', зап. пах. (котгархи) lınghño 'переходить, проходить'.

Несомненных случаев дезаспирации более ранних звонких придыхательных в рамбани не отмечено, в то время как для сираджи Дж. Грирсон [Grierson 19192: 434] приводит два подобных примера: butō '(он) был' при др.-инд. bhūta- 'бывший, ставший' и bučč $\bar{a}$ 'голодный’ (< *bhuččhā) при др.-инд. bubhukșā- ‘голод’, хинди bhūkhā, пандж., лахнда $b h u k k h \bar{a}$ 'голодный'. Относительно второго примера следует отметить, что он в действительности демонстрирует не потерю придыхания, а полную утрату более старого звонкого придыхательного в интервокальном положении ${ }^{10}$. Поэтому едва ли он может служить весомым аргументом в пользу принадлежности сираджи к дардской группе. Кроме того, П.К. Коуль отмечает несомненно родственное вышеприведенному прилагательному существительное bhuс̌с̌ 'голод' с начальной аспиратой [Koul 20061: 329]. Вне зависимости от того, связано ли расхождение в записях с неточностью фиксации или с реально существующим в языке свободным варьированием начального придыхательного и непридыхательного в данном слове ${ }^{11}$, рассматриваемый пример в любом случае нельзя считать надежным и бесспорным.

Происхождение первого из приведенных выше примеров представляется неясным. Вопрос вызывает причина не только утраты древнего придыхания у начального $b h$, но и сохранения интервокального $t$, поскольку в сираджи имеются несомненные примеры выпадения последнего (ср. bhrā ‘брат’ при др.-инд. bhrātar-, šōu '100’ при др.-инд. śatam). Возможное объяснение как отсутствия придыхательного, так и наличия согласного $t$ в интервокальном положении в форме butō (а также и в других формах связки прошедшего времени, образованных от основы but-) можно, на наш взгляд, предложить, не связывая ее с др.-инд. bhūta-. Интересной представляется этимология Р. А. Тернера, сопоставившего в своем сравнительном словаре данную форму с др.-инд. vrtta- 'повернувшийся; округлый; завершенный; прошедший, истекший’ [Turner 1966: 699]. С точки зрения семантики данное сравнение следует признать правдоподобным, особенно учитывая, что у ряда новоиндийских рефлексов указанного древнеиндийского образования основным значением является 'проходить (о времени)' (хинди bït-, ория, зап. пах. (котгархи) bit-, гудж. vitt-), из которого вполне тривиальным образом могло развиться значение связки

9 Этимологически, по-видимому, неотделимо от др.-инд. bharati ‘несет’ [Turner 1966: 535].

${ }^{10}$ Начальный придыхательный в новоиндийских языках в данном слове вторичен и представляет собой результат относительно позднего стяжения. Непосредственным прототипом современных форм с начальным bh является среднеиндийская форма buhukkhā-, зафиксированная в пракритах, в которой ларингальный $h$ регулярным образом отражает древнеиндийский интервокальный $b h$.

11 Такое варьирование может быть связано, например, с наличием в слове двух аспират. 
прошедшего времени ${ }^{12}$. Единственной фонетической нерегулярностью является упрощение старой интервокальной геминаты $t t$ до одиночного $t^{13}$. Эта нерегулярность, однако, не представляется необъяснимой. Элемент -t- является в диалекте сираджи показателем имперфекта. Он присоединяет личные окончания, причем парадигма спряжения идентична таковой глагола-связки в прошедшем времени ${ }^{14}$ (cp. $1 \mathrm{Sg}-t \bar{e}, 2 \mathrm{Sg}-t \bar{e}, 3 \mathrm{Sg}-t \bar{o}$, $1 \mathrm{Pl}$-tā, 2 Pl -tath, 3 Pl -tā и парадигму связки: 1 Sg butē, 2 Sg butē, 3 Sg butō, 1 Pl butā, 2 Pl butath, 3 Pl butā). Можно предположить, что формы связки, продолжающие древнее vrtta-, на определенном историческом этапе стали восприниматься как формы имперфекта. Это могло вызвать парадигматическое выравнивание, результатом которого и явилось возникновение одиночного $t$ на месте более ранней геминаты. Таким образом, рассмотренный пример вовсе не является несомненным случаем дезаспирации старого звонкого придыхательного.

Еще одним примером потери древнего придыхания является сир. baḍō 'резать, pyбить' при др.-инд. vardhayati ‘режет, разделяет'. В этом случае, однако, потеря придыхания вполне может объясняться сложной для произношения аспираты позицией перед согласным: данный глагол засвидетельствован только в форме косвенного падежа инфинитива (badne $)$, показатель которого начинается с согласного $n$.

В связи с вопросом о дезаспирации в сираджи следует отметить, что Р. А. Шмидт и В. К. Кауль в своем словнике не отмечают придыхание у звонких в ряде лексем, в которых другие исследователи (Т. Г. Бейли, Дж. Грирсон, П. К. Коуль) фиксируют звонкую аспирату (ср., напр., gar 'дом’ [Schmidt, Kaul 2008: 287] при ghar [Bailey 1903: 36; Grierson 19192: 443], gōr 'камень' [Schmidt, Kaul 2008: 292] при ghōr [Koul 20061: 326]). Поскольку данное расхождение в фиксации охватывает лишь часть примеров, и как таковые исторические звонкие придыхательные отмечаются и в словнике Р. А. Шмидт и В. К. Кауля (cp., напр., bhädro 'название месяца' [Schmidt, Kaul 2008: 290]; bhōro 'шмель' [Schmidt, Kaul 2008: 293]; ghōro ‘лошадь’ [Schmidt, Kaul 2008: 293]; bheḍū ‘баран’ [Schmidt, Kaul 2008: 294]; ghās 'трава' [Schmidt, Kaul 2008: 295]), едва ли есть какие-либо основания предполагать позднюю дезаспирацию в сираджи. Вероятно, дело здесь в неточности записи. При этом вряд ли можно упрекнуть в неаккуратности Т. Г. Бейли, чьи работы по индоарийским и дардским языкам хорошо зарекомендовали себя в смысле качества фиксации материала, и Дж. Грирсона, позаимствовавшего основную часть материала по сираджи у Т. Г. Бейли. Скорее всего, непоследовательность в данном случае проявили именно Р. А. Шмидт и В. К. Кауль. Поэтому мы не считаем целесообразным ориентироваться на записи этих исследователей в том, что касается рефлексации древних звонких аспират ${ }^{15}$.

12 Показательно также наличие в некоторых индоарийских языках глагола-связки, восходящего к древнеиндийскому корню vart- (ср., напр., авадхи $b \bar{a} t-$ ).

${ }^{13}$ Ср. сохранение древней геминаты, наример, в ditto 'данный' (< *ditta- [Turner 1966, 351]) при др.-инд. datta-.

14 Эта парадигма характерна для всех непереходных глаголов в прошедшем времени. Современные личные формы в ней, по всей видимости, восходят к более ранним сочетаниям причастий с местоименными суффиксами.

15 Тем не менее, следует заметить, что материалы Р. А. Шмидт и В. К. Кауля содержат некоторые интересные факты. Так, в ряде слов с историческим звонким придыхательным эти исследователи отмечают на соседнем гласном восходящий тон (ср. bráu ‘брат' при др.-инд. bhrātar-, ср. также bhrā, brhā у Дж. Грирсона и brhā у Т. Г. Бейли; dútm 'дым’ при др.-инд. dhūma-). Неясно, насколько точны эти записи. Во всяком случае, нельзя исключить, что В. К. Кауль и Р. А. Шмидт приняли за тон слабое придыхание перед долгим гласным. Однако если их нотация действительно отражает реальную картину, то можно предположить для сираджи развитие фонологического тона на месте древней аспирации. Явление это, однако, позиционное (по 
Таким образом, доступный материал не дает нам совершенно никаких оснований предполагать для сираджи и рамбани фронтальное совпадение древних звонких придыхательных со звонкими. Противопоставление двух серий в рассматриваемых диалектах, по всей видимости, сохранилось в большинстве позиций, что уже само по себе не позволяет относить их к дардской группе, а следовательно, и считать их диалектами кашмири. Следует отметить, что данный аргумент является более веским, нежели рассмотренное выше стяжение краткого дифтонга, так как последнее теоретически могло иметь место в рамбани и сираджи и в относительно позднюю эпоху, как это случилось в целом ряде дардских и иранских языков.

В качестве одного из аргументов в пользу близости сираджи и рамбани к кашмири Дж. Грирсон приводит наличие в этих языках переходов *̌c > с и *̌j> z [Grierson 19192: 434, 459]. Подобное развитие, однако, характерно и для ряда индоарийских языков, в частности, для некоторых языков группы пахари: котгархи, бхадарвахи, бхалеси [Ваiley 1908; Varma 1948; Hendriksen 1976-86]. В самом кашмири оно датируется достаточно поздней эпохой [Коган 20092], и его никоим образом нельзя считать классифицирующей особенностью дардских языков. Кроме того, некоторые факты фонетики диалекта сираджи заставляют поставить под вопрос само наличие дентализации среднеязычных аффрикат как фонологически значимого явления. В записях Т. Г. Бейли [Вailey 1903], высокая точность которых является общепризнанной, согласные $z$ и $j$ иногда отмечаются в одинаковой позиции в одном и том же корне (ср. az и ajj 'сегодня'). То же можно сказать и о согласных $z$ и $d z$ (ср. uzāri ‘ растратив’, udzārīūeñ ‘(он) растратил’). Аффриката $d z$ на месте ожидаемого $z$

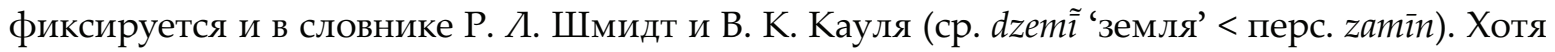
недостаток материала пока не позволяет делать какие-либо окончательные выводы, есть основания полагать, что согласные $z, d z$ и $j$ в сираджи находятся в отношении свободного варьирования. Такая гипотеза позволяет объяснить, например, двоякое отражение $z$ в

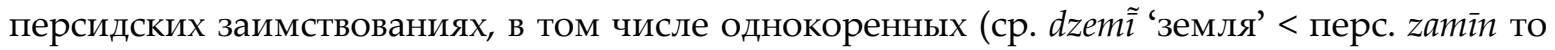

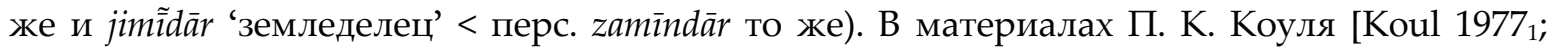

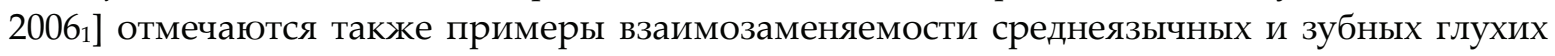
аффрикат (с̌ и с, čh и ch): čarhhōllī ‘птица' [Koul 20061: 328] и caroliyẽ 'птицы’ [Koul 2006 1 : 349]; čō и со̄ ‘яблоко’ [Koul 20061: 349]; chittō ‘белый’ [Koul 20061: 327] и čhittō ‘белый’ [Koul 20061: 332]. Возможно, однако, что запись подобных примеров не отражает реального произношения. В принятой П. К. Коулем системе транскрипции на основе письма деванагари дентальные аффрикаты обозначаются знаками для среднеязычных с точкой внизу. Нельзя исключить, что колебания в записях связаны с тем, что при фиксации или при последующем издании материалов точка ставилась не во всех необходимых случаях. Поэтому если для среднеязычных и дентальных звонких аффрикат свободное варьирование представляется вероятным, то для их глухих коррелятов предполагать таковое нет весомых оснований.

Таким образом, из тех историко-фонетических черт рассматриваемых диалектов, которые в прошлом пытались представить в качестве «дардских», в действительности ни одна к таковым не относится. В общем и в целом можно с полной ответственностью констатировать, что доступный в настоящее время языковой материал не позволяет обнаружить никаких фактов исторической фонетики, дающих основания относить сираджи и рамбани к дардской группе. При этом имеются несомненные указания на невозможность такой классификации ${ }^{16}$. В то же время, не удалось выявить никаких существенных

крайней мере, не зафиксировано ни одного примера восходящего тона вне позиции перед долгим гласным) и весьма недавнее, поскольку еще в начале $\mathrm{XX}$ века не отмечено никаких признаков его наличия.

${ }_{16}$ Речь идет, прежде всего, о сохранении оппозиции древней звонкой и звонкой придыхательной серии. 
историко-фонетических расхождений, препятствующих причислению сираджи и рамбани к индоарийской группе. Их фонологические системы, по-видимому, могут быть выведены из древнеиндийской, что неверно для фонологической системы кашмири и других дардских языков.

Гипотеза о принадлежности сираджи и рамбани к дардской группе не подтверждается и данными морфологии. Большая близость морфологической системы этих диалектов к таковой соседних индоарийских языков, нежели к кашмирской, уже отмечалась в некоторых работах [Edelman 1983: 298-299]. Единственной чертой морфологии, сближающей рамбани и сираджи с кашмири, является наличие местоименных суффиксов, присоединяемых к глагольным формам ${ }^{17}$. Дж. Грирсон приводил эту особенность в качестве одного из основных аргументов в пользу классификации сираджи как кашмирского диалекта. Этот аргумент, однако, едва ли можно считать решающим, поскольку местоименные суффиксы имеются и в некоторых индоарийских языках, в частности, в синдхи, в диалектах западного и северо-западного Панджаба и смежных территорий ${ }^{18}$. В языках пахари они не отмечены, но следует учесть, что многие из этих языков до сих пор описаны весьма фрагментарно, и уверенно говорить об отсутствии в них данного явления пока рано ${ }^{19}$.

Неясно, в какую эпоху система суффигированных местоимений в сираджи и рамбани окончательно сложилась в современном виде. Некоторые факты могут свидетельствовать об относительно позднем происхождении некоторых суффиксов. Так, показатели

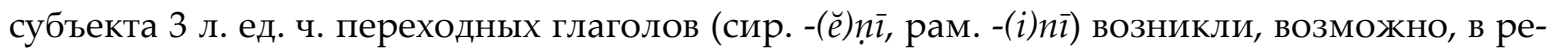
зультате вторичной энклизы указательного местоимения в форме эргативного падежа ед. ч. (сир. уеฺ̣ / teṇi ${ }^{20}$, рам. tịn $)$ и последующих фонетических изменений. Данная гипотеза позволяет более правдоподобно объяснить наличие в приведенных местоименных суффиксах конечного долгого $\bar{\imath}$, а также начальных кратких $\breve{e}$ и $i$, нежели сопоставление с кашмирским субъектным показателем 3 л. ед. ч. -n-, продолжающим, скорее всего, одну из форм древнего указательного местоимения *ana-21. Таким образом, представляется

${ }^{17}$ Их называют также суффигированными (энклитическими) местоимениями или местоименными энклитиками. В сираджи отмечены следующие суффигированные местоимения: -m (показатель субъекта 1 л. ед. ч. при переходных глаголах в перфектных временах), -t (показатель субъекта 2 л. ед. ч. при переход-

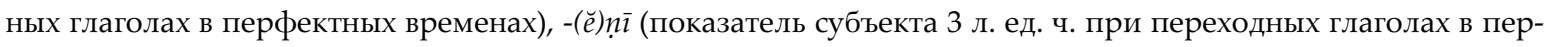
фектных временах), -s (показатель непрямого объекта 3 л. ед. ч.) [Grierson 19192: 450-451]. В рамбани система местоименных суффиксов идентична таковой в сираджи. Набор показателей тот же, но с небольшими

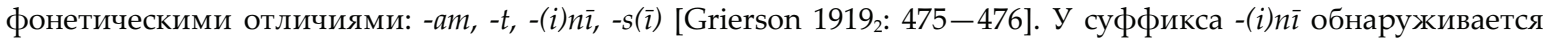
тенденция к расширению функций и превращению в показатель прошедшего времени для всех лиц [Grierson $1919_{2}$ : 476].

${ }^{18}$ Интересно, что в этих диалектах обнаруживаются функционально тождественные этимологические соответствия таким суффигированным местоимениям сираджи, как - $m$ и -s.

${ }^{19}$ В этой связи небезынтересен также тот факт, что в диалектах северо-западного Панджаба, т. е. области, непосредственно примыкающей к округу Джамму, система суффигированных местоимений, повидимому, постепенно распадается. Уже в начале XX века местоименные суффиксы 1 и 2 л. не имели там широкого распространения [Grierson 1919: 431]. В диалекте пунчхи, распространенном восточнее, в пределах округа Джамму, единственным широко употребительным суффигированным местоимением является показатель 3 л. ед. ч., в то время как показатель 2 л. ед. ч. не отмечен вовсе [Grierson 1919.: 512]. Нельзя исключить, что в языках группы пахари, ареал которых расположен далее на восток, в прошлом имел место аналогичный процесс, зашедший, впрочем, еще дальше и приведший к полной утрате местоименных суффиксов.

${ }^{20}$ Косой чертой разделены формы местоимений ближнего и дальнего дейксиса. В рамбани форма эргатива указательного местоимения ближнего дейксиса не отмечена в текстах.

${ }^{21}$ См. [Turner 1966: 14], где кашмирское суффигированное местоимение ошибочно приведено в форме -an. 
вероятным, что в сравнительно недавнем прошлом в сираджи и рамбани имело место некоторое расширение системы суффигированных местоимений за счет введения в нее новых, исторически несуффиксальных и неэнклитических элементов. Катализатором этого процесса вполне могло быть влияние соседнего кашмири. Возможно, во многом благодаря этому влиянию система местоименных суффиксов в рассматриваемых диалектах сохранялась долгое время, не обнаруживая тенденции к разрушению.

Еще одной изоглоссой, объединяющей сираджи и рамбани с кашмири, является общая основа форм связки настоящего времени с̌h-. Эту черту скорее следует рассматривать не как морфологическую, а как лексическую или, по крайней мере, как находящуюся на стыке морфологии и лексики. Ее никоим образом нельзя считать существенной для генетической классификации: этимологически родственные формы связки, восходящие к древнеиндийскому корню kși- 'проживать, существовать', имеются во многих индоарийских языках 22. Засвидетельствована данная основа, в частности, в соседнем языке бхалеси (necchi 'не есть, не является'). Более того, есть основания полагать, что распространение ее в кашмири связано с индоарийским влиянием. Этимологические соответствия кашмирским формам связки в других дардских языках весьма немногочисленны: паш. (чиласский диал.) ос- 'быть'23 и, возможно, торв. с̌̄ - форма связки наст. вр. ж. p..$^{24}$. Показательно их отсутствие в близком к стандартному кашмири диалекте каштавари, где основа глагола-связки th- восходит, как и в торвали и многих других дардских языках ${ }^{25}$, к общеарийск. *stā-. Даже если основа čh- в кашмири является исконной, представляется вероятным, что ее утверждение в качестве единственной для связки в настоящем времени произошло благодаря тесным контактам с индийскими языками, возможно, с близкородственными бхалеси языками группы пахари.

Дексика сираджи и рамбани характеризуется наличием изоглосс, как общих с кашмири, так и общих с новоиндийскими языками. Последние при этом явно преобладают над первыми. Нет сомнения, что подобная ситуация могла сложиться только вследствие интенсивных межъязыковых контактов и выявление заимствований, усвоенных в ходе этих контактов рассматриваемыми диалектами, представляет собой сложнейшую задачу. Решение этой задачи является, однако, необходимым условием для установления реального генетического положения сираджи и рамбани. Наиболее интересным материалом для исследования является, разумеется, базисная лексика, в частности, ее, возможно, наиболее удачная и часто используемая выборка - стословный список М. Сводеша. Сразу следует оговориться, что проведение лексикостатистических подсчетов возможно только для диалекта сираджи. Материал по рамбани чрезвычайно скуден, и едва ли не большая часть слов стандартного списка не зафиксирована. Однако, как уже говорилось, генетическая близость рамбани и сираджи едва ли может быть подвергнута сомнению. Поэтому результаты, полученные для последнего, можно будет считать имеющими силу и для первого.

Исследование лексики сираджи в рамках метода лексикостатистики сопряжено с некоторыми специфическими трудностями. Проблема выделения заимствований в сто-

22 Эти формы см., например, в статье ākșēti в словаре Р.Тернера [Turner 1966: 46].

${ }^{23}$ Возможно, заимствование [Morgenstierne 1956: 3].

24 Формы связки м. p. thī (ед. ч.) и thī (мн. ч.), несомненно, продолжают производные общеарийск. *stā‘стоять'. Форму ж. р. (общую для обоих чисел) следует, по-видимому, считать супплетивной. Предположение Дж. Грирсона о возникновении $\check{c}(<* c h)$ из более раннего th в результате палатализации [Grierson 1929: 14] представляется нам менее вероятным: ни одного бесспорного примера подобного развития в торвали не отмечено.

${ }^{25}$ Ср., напр., тир. thī (м. р.), thē (ж. р.), г.-б. thana (м. р.), thini (ж. р.), башк. thī (м. р.), thī (ж. р.), пхал. thī (м. и ж. р.) '(он) есть, является', паш. (диал. лауровани) th- 'быть, становиться’. 
словном списке, хорошо знакомая каждому компаративисту, усугубляется в нашем случае неясностью генетической принадлежности языка. Действительно, если, например, вслед за Дж. Грирсоном считать, что сираджи является кашмирским диалектом и, следовательно, относится к дардской группе, все слова из списка Сводеша, обнаруживающие несомненные семантически тождественные этимологические соответствия в индоарийских языках, но не имеющие таковых в дардских, можно с полным основанием рассматривать как заимствованные и не учитывать при подсчетах. С другой стороны, если, подобно Р. А. Шмидт и П. К. Коулю, считать сираджи одним из языков группы пахари (т. е. одним из индоарийских языков), заимствованиями с большой степенью вероятности можно считать слова, общие для сираджи и кашмири, но отсутствующие в новоиндийских языках.

Данная ситуация, на первый взгляд напоминающая порочный круг, в действительности не является безвыходной. Проведенный выше анализ исторической фонетики позволяет выбрать из двух гипотез более правдоподобную. Таковой следует считать «индоарийскую» гипотезу, предложенную П. К. Коулем и Р. Я. Шмидт. Весьма важным для нас является также то обстоятельство, что доля заимствований в стословном списке, как правило, относительно низка. Если учесть также весьма значительную величину разрыва в процентах соответствий между разными новоиндийскими языками с одной стороны и новоиндийскими и дардскими языками - с другой ${ }^{26}$, можно ожидать, что лексикостатистические подсчеты, выполненные даже без выделения заимствований (т. е. при рассмотрении их как схождений с языком-донором, в нашем случае - с кашмири или неким индоарийским языком), хотя и заметно исказят в некоторых аспектах реальную картину языковой дивергенции (в частности, дадут неверные датировки), но при этом все же покажут достаточно близкое к истинному положение исследуемого языка на родословном древе. Поэтому нам представляется целесообразным проведение лексикостастистического анализа в три этапа. На первом этапе будет произведен предварительный подсчет при невыявленных (или не полностью выявленных) заимствованиях с целью установления соотношения долей сираджи-дардских и сираджи-индоарийских соответствий. Это соотношение явится основанием для предварительной гипотезы о генетическом положении сираджи. На втором этапе, исходя из выдвинутой гипотезы, будут выявлены вероятные заимствования (дардские или индоарийские) в стословном списке рассматриваемого диалекта. Наконец, на третьем этапе, будут проведены окончательные подсчеты в рамках стандартного лексикостатистического метода.

Стословный список сираджи приведен в приложении, а списки привлекаемых для сравнения индоарийских и дардских языков - в нашей недавней работе [Коган 2005]. Дексический материал сираджи взят главным образом из работы [Schmidt, Kaul 2008] и дополнен данными, зафиксированными в [Grierson 19192] и [Koul 2006 $]$. Четыре слова

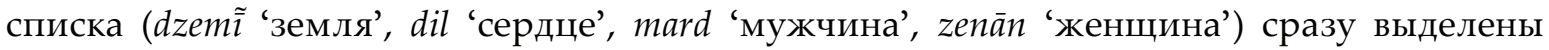
нами как иноязычные: это несомненные заимствования из персидского языка27. Кроме того, заимствованиями, вероятнее всего, являются слова с̌аkkи 'укус' (именная часть сложного глагола с̌akku dé- 'кусать') 28 и с̌ānī 'луна', поскольку в них не обнаруживается

${ }^{26}$ Средняя доля совпадений между дардскими и новыми индоарийскими языками составляет 43,5\% [Коган 2005: 176], между разными новоиндийскими языками - 69\%.

${ }^{27}$ Ср. кл.-перс. zamīn 'земля', dil 'сердце', mard 'мужчина', zanāna 'женский'.

${ }^{28}$ Слово отмечено в [Schmidt, Kaul 2008]. Данное слово было заимствовано также в некоторые языки группы пахари (ср. котгархи с̌ak- 'кусать'). Из вероятных исконных соответствий ср., напр., хиндко саk, синдхи саkи 'укус'. 
предполагаемый для сираджи переход $\check{c}>c^{29}$. Наличие же согласного $j$ не считается нами признаком иноязычного происхождения слова, поскольку, как уже говорилось, есть основания предполагать свободное варьирование среднеязычных и зубных звонких аффрикат в сираджи.

Интересной особенностью стословного списка сираджи является то, что ряд значений выражается в нем двумя синонимами, один из которых обнаруживает точные этимологические соответствия в индоарийских языках, а другой - в дардских, но, как правило, не в индоарийских (idd 'живот', ср. кашм. yӗd то же и рёt 'живот', ср. хинди, пандж., гудж., бенг., зап. пах. (котгархи) peț то же

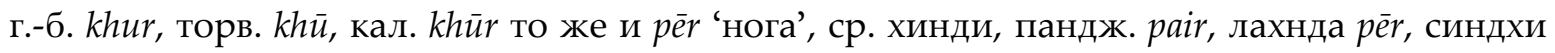
per то же; kuțh 'колено', ср. кашм. kŏțh, шина kuțo, пхал. khuțu, май., башк. kuțh, торв. kuț то же и јаппй 'колено', ср. зап. пах. dzạฺu (котгархи), јапฺй (химачали), ја̄nnhu (кулуи, ман-

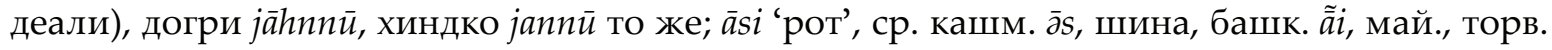

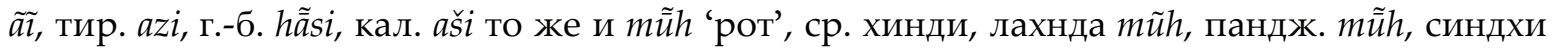

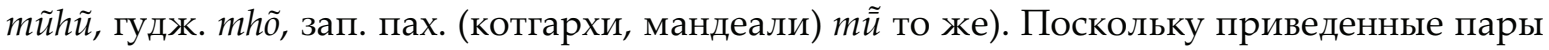
синонимов обнаруживаются в языке, для которого признается сильное воздействие со стороны соседей, представляется весьма вероятным, что причиной подобной ситуации являются именно языковые контакты. Иными словами, есть все основания полагать, что, по крайней мере, один из членов каждой пары представляет собой заимствование. Выявление таких заимствований, как уже говорилось, будет возможным только после предварительных лексикостатистических подсчетов.

Для одного из слов стословного списка сираджи - čhittō, chittō31 ‘белый’ выбор между отнесением к индоарийскому или дардскому лексическому пласту сопряжен с некоторыми трудностями. Это слово, по всей видимости, представляет собой результат контаминации одного из новоиндийских обозначений белого цвета (ср. хинди, пандж., хиндко, догри, зап. пах. (химачали, мандеали) cițtā, лахнда cițā, годжри cițo) с одним из дардских (ср. кашм. čhot 'белый' < *kș̌aita-32). Дардская и индоарийская формы, несмотря на созвучие, неродственны друг другу. Поскольку для базисной лексики обычно принимается своеобразная «презумпция исконности» (т. е. слово считается исконным, если нет фактов, однозначно свидетельствующих о его иноязычном происхождении), нам представляется целесообразным на стадии предварительных подсчетов при сравнении с индоарийскими языками гипотетически рассмотреть данное слово как индоарийское (т. е. считать придыхание у начальной аффрикаты и дентальные согласные вместо ожидаемых церебральных результатом контаминации с кашм. čhot), а при сравнении с дардскими языками - как дардское (т. е. считать гласный $i$ и геминацию $t$ неэтимологическими и объяснять их появление индийским влиянием). Еще раз оговоримся, что подобная «двойственная» трактовка является лишь предварительной мерой, оправданной на первом этапе исследования (при рассмотрении возможных вариантов и оценке их

${ }^{29}$ Об этом переходе см. выше. Поскольку противопоставление дентальных и среднеязычных аффрикат нет весомых оснований считать нефонологичным, мы рассматриваем изменение $\check{c}>c$ в качестве одной из характерных черт исторической фонологии сираджи. Наличие же фонологически значимого перехода $j>z$, как уже говорилось, не представляется бесспорным. Поэтому наличие аффрикаты $j$, на наш взгляд, не может считаться надежным свидетельством иноязычного происхождения слова. Обозначение луны, повидимому, заимствовано из индоарийского источника, где оно продолжает производное от др.-инд. сапdra'луна'. Новоиндийские рефлексы последнего см. в [Turner 1966: 252].

30 Слово, по-видимому, дравидийского происхождения (см. [Коган 2005: 157]).

31 Форма с начальной зубной аффрикатой ch зафиксирована в [Koul 20061].

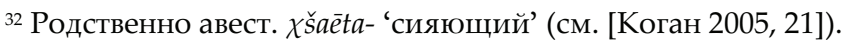


вероятности), но не на последующих, когда из двух теоретически возможных решений будет выбрано наиболее обоснованное.

Ниже в двух таблицах приводятся результаты предварительных лексикостатистических подсчетов.

Таблица 1. Предварительно вычисленные проценты совпадений между стословными списками сираджи и индоарийских языков.

\begin{tabular}{l|c}
\hline Язык & $\begin{array}{c}\text { Процент совпадений } \\
\text { с сираджи }\end{array}$ \\
\hline хинди & $71 \%$ \\
\hline панджаби & $72 \%$ \\
\hline лахнда & $74 \%$ \\
\hline синдхи & $68 \%$ \\
\hline гуджарати & $66 \%$ \\
\hline маратхи & $61 \%$ \\
\hline бенгали & $66 \%$ \\
\hline ассамский & $58 \%$ \\
\hline непали & $67 \%$ \\
\hline пахари (котгархи) & $75 \%$ \\
\hline
\end{tabular}

Таблицุ 2. Предварительно вычисленные проценты совпадений между стословными списками сираджи и дардских языков.

\begin{tabular}{l|c}
\hline Язык & $\begin{array}{c}\text { Процент совпадений } \\
\text { с сираджи }\end{array}$ \\
\hline кашмири & $54 \%$ \\
\hline шина & $46 \%$ \\
\hline пхалура & $50 \%$ \\
\hline гавар-бати & $52 \%$ \\
\hline пашаи & $48 \%$ \\
\hline кховар & $40 \%$ \\
\hline калаша & $49 \%$ \\
\hline
\end{tabular}

Цифры, приведенные в таблицах, как нам представляется, четко и недвусмысленно указывают на принадлежность сираджи к индоарийским, а не к дардским языкам. Средний процент совпадений, полученный на основании этих цифр, составляет для сираджи и индоарийских языков 67,8\%, для сираджи и дардских - 48,4\%. Разрыв почти в 20\%, несомненно, не может объясняться исключительно контактными явлениями, такими как заимствование или вторичный «подскок» доли схождений в списках контактирующих близкородственных языков ${ }^{33}$. Поэтому его следует считать именно отражением

${ }^{33}$ Как указывает С. А. Старостин, такой «подскок», вызванный тем, что при тесных контактах между близкородственными языками в их стословных списках иногда сохраняются и заменяются одни и те же слова, может достигать лишь 5-6\% [Старостин 1989: 35]. В нашем же случае, если предположить, что си- 
определенной генетической характеристики рассматриваемого диалекта. Внимания заслуживает также тот факт, что наиболее высокий процент совпадений сираджи обнаруживает с языками Северной и Северо-Западной Индии: хинди, панджаби, лахнда, котгархи.

Принимая во внимание результаты предварительных подсчетов, мы можем снова обратиться к проблеме заимствований в стословном списке сираджи. Наиболее вероятным иноязычное происхождение представляется для слов, имеющих этимологические параллели в дардских языках, но не имеющей таковых в индоарийских. Так, из рассмотренных выше пар синонимов такие слова, как iḍ 'живот', khor 'нога' и kuț 'колено' можно с полным основанием признать дардскими заимствованиями и исключить из стословного списка, оставив лишь их индоарийские эквиваленты: $p \bar{e} t, p \bar{e} r$ и jannū соответственно. Усвоенными из дардского источника (вероятнее всего, из кашмири) следует считать также țhūl 'яйцо' (ср. кашм. țhūl то же) и јиа̄n 'хороший' (ср. кашм. jān то же) ${ }^{34}$. Надежных индоарийских соответствий у этих слов также не прослеживается.

Некоторые слова стословного списка сираджи теоретически могли бы являться общими дардско-сираджи архаизмами, поскольку у них обнаруживаются семантически тождественные соответствия в древних арийских языках (ср. сир. $\bar{a} s i$ 'рот' при др.-инд. ās-, āsya-, авест. āh- то же ${ }^{35}$; сир. šunā 'собака' при др.-инд. śvan-, авест. span-, кашм. hūn,

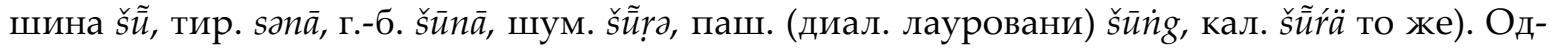
нако примечательно, что в новоиндийских языках эти слова, как правило, отсутствуют. Нет их, в частности, и в языках Северной и Северо-Западной Индии, обнаруживающих наибольшую близость к сираджи. Здесь основные названия рта и собаки продолжают соответственно др.-инд. тиkha- и древнюю основу *kut- (ср. пракр. kutta- 'собака', а также

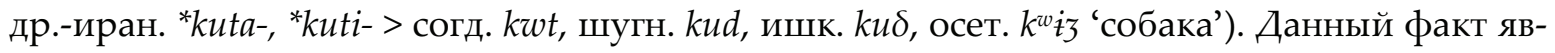
ляется сильным аргументом в пользу заимствования сир. $\bar{s} s i$ 'рот' и šun̄̄ 'собака' из соседнего кашмири ${ }^{36}$. Во всяком случае, иноязычное происхождение в данном случае представляется более вероятным, нежели сохранение общих архаизмов, утраченных в близкородственных языках ${ }^{37}$.

Таким образом, стословный список сираджи, который будет использоваться нами для окончательных лексикостатистических подсчетов, содержит следующие заимствова-

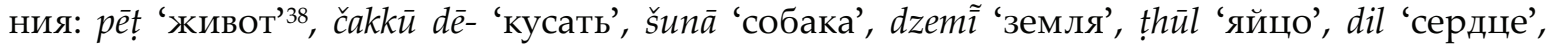
mard 'мужчина', čānī 'луна', zenān 'женщина'. Вероятные дардские заимствования, имеющие синонимы другого происхождения (idd 'живот', khor 'нога', juān 'хороший' и $k u t ̣ h$ 'колено'), как уже говорилось, в список не включались. Общее число заимствова-

раджи - диалект кашмири, придется допустить «подскок» в проценте соответствий с индоарийскими языками почти на 20\%, что, по-видимому, невероятно.

34 У последнего слова есть синоним rolō, который и будет включен нами в окончательный вариант стословного списка сираджи.

35 Дардские соответствия этого слова см. выше.

${ }^{36}$ Для последнего слова следует предполагать заимствование в эпоху, предшествовавшую кашмирскому передвижению сибилянтов, частным случаем которого был переход *̌s > h (см. [Коган 20092]).

${ }_{37} \mathrm{~B}$ данной связи интересно отметить, что название рта, родственное др.-инд. $\bar{a} s y a-$, зафиксировано

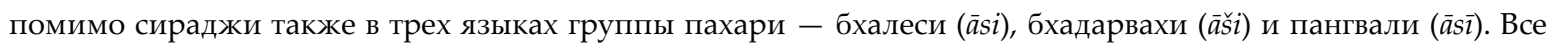
эти языки распространены в непосредственной близости от Кашмирской долины, и во всех них обнаруживаются явные следы влияния кашмири. Ни в одном другом языке пахари, как, впрочем, и вообе ни в одном другом новоиндийском языке, данный этимон не отмечен.

${ }^{38}$ Как говорилось выше, это слово, по всей видимости, является старым дравидизмом в индоарийских языках. 
ний (9) отнюдь не представляется аномально высоким. Оно равно числу заимствований, например, в таких индоарийских языках, как маратхи и бенгали и лишь немногим меньше такового в хинди ${ }^{39}$.

Окончательные лексикостатистические подсчеты ${ }^{40}$, проведенные после выделения заимствований дали следующие результаты: табл. 3 и 4.

Средние доли совпадений составляют 70,4\% для сираджи и индоарийских языков и 46,4\% для сираджи и дардских. Данные цифры, как нам представляется, ясно и недвусмысленно указывают на принадлежность сираджи к индоарийской группе. Принимая во внимание сказанное выше о несомненной генетической близости сираджи и рамбани, отнесение к индоарийским языкам следует считать правомерным и для последнего.

В общем и в целом можно сказать, что при всей скудости данных по диалекту сираджи комплексное исследование этих данных позволило прийти к однозначному выводу относительно его генетического положения. Интересно, что факты разных языковых уровней при этом как бы дополняют друг друга. Данные исторической фонетики (в частности, сохранение в сираджи оппозиции древних звонкой и звонкой придыхательной серий) четко указывают на невозможность классификации этого диалекта как дардского. При этом, однако, они не свидетельствуют однозначно в пользу «индоарийской гипотезы»: стяжение краткого дифтонга, как уже говорилось, могло быть поздним явлением, а сохранение звонких придыхательных представляет собой общий сираджи-индоарийский архаизм и тем самым не может служить основанием для объединения в одну генетическую общность. Однако результаты лексикостатистических подсчетов вносят в вопрос о месте сираджи в генетической классификации арийских языков окончательную ясность.

\section{3. К вопросу о генетических отношениях стандартного кашмири и диалектов погуди и каштавари}

Диалекты погули и каштавари распространены непосредственно к югу и юго-востоку от Кашмирской долины в долинах Погул, Паристан и Каштавар, входящих ныне в округ Джамму индийского штата Джамму и Кашмир. Оба диалекта обнаруживают значительную материальную близость к стандартному кашмири, что неоднократно отмечалось исследователями [Bailey 1903: 51, 61; Grierson 19192: 402; Koul, Schmidt 1984; Kaul 1995].

${ }^{39}$ В стословном списке хинди 8 заимствований.

${ }^{40}$ Строго говоря, приводимые ниже цифры также являются предварительными. Они могут измениться, например, в том случае, если после введения в научный обиход нового лексического материала по диалекту сираджи станут известны исконные синонимы каких-либо заимствований в стословном списке. Следует также отметить, что два слова, отмеченные нами как исконные, в действительности могут являться дардскими заимствованиями. Это прилагательные nīlo 'зеленый' и haldro 'желтый'. Обладая надежными семантически тождественными соответствиями в ряде языков дардской группы (ср. кашм. n’ūl, шина, пхал. nīlu, май. nīl, г.-б. nīla 'зеленый'; кашм. l'odur, шина haližu, паш. (диал. курангали) ārilo, шум. ärila 'желтый’), они не обнаруживают таковых в тех новоиндийских языках, которые по данным лексикостатистики обнаруживают наибольшую генетическую близость к сираджи (хинди, панджаби, лахнда, котгархи). В подобной ситуации гипотеза о заимствовании представляется вполне естественной. Тем не менее, поскольку у данных слов имеются древне- и среднеиндийские прототипы (ср. др.-инд. nīla- 'темно-синий, темнозеленый', пракр. ṇīla- 'синий, зеленый'; др.-инд. haridra- 'желтое сандаловое дерево', пракр. halidda- 'желтый’), а также соответствия с тождественной семантикой в отдельных (пусть не самых близких генетически) новоиндийских языках (ср. гудж. līlo 'зеленый'; бенг. holode, acc. halodhiya 'желтый’), мы предпочли рассматривать их как исконные. 
Таблицุ 3. Проценты совпадений между стословными списками сираджи и индоарийских языков, полученные в результате окончательных лекскостатистических подсчетов.

\begin{tabular}{l|c}
\hline Язык & $\begin{array}{c}\text { Процент совпадений } \\
\text { с сираджи }\end{array}$ \\
\hline хинди & $74 \%$ \\
\hline панджаби & $76 \%$ \\
\hline лахнда & $77 \%$ \\
\hline синдхи & $70 \%$ \\
\hline гуджарати & $68 \%$ \\
\hline маратхи & $64 \%$ \\
\hline бенгали & $68 \%$ \\
\hline ассамский & $61 \%$ \\
\hline непали & $70 \%$ \\
\hline пахари (котгархи) & $76 \%$ \\
\hline
\end{tabular}

Таблицза 4. Проценты совпадений между стословными списками сираджи и дардских языков, полученные в результате окончательных лекскостатистических подсчетов.

\begin{tabular}{l|c}
\hline Язык & $\begin{array}{c}\text { Процент совпадений } \\
\text { с сираджи }\end{array}$ \\
\hline кашмири & $47 \%$ \\
\hline шина & $44 \%$ \\
\hline пхалура & $49 \%$ \\
\hline гавар-бати & $50 \%$ \\
\hline пашаи & $47 \%$ \\
\hline кховар & $40 \%$ \\
\hline калаша & $48 \%$ \\
\hline
\end{tabular}

Вместе с тем и погули, и каштавари обладают рядом черт, в том числе архаичных, отличающих их от говоров собственно Кашмира, включая и сринагарский - основу литературного языка. Оба диалекта подверглись чрезвычайно сильному влиянию соседних индоарийских языков группы пахари, что привело к появлению некоторых «неясностей» в исторической фонетике, связанных, прежде всего, с нерешенностью вопроса о критериях разграничения исконной и заимствованной лексики. Таким образом, если генетическая близость погули и каштавари к стандартному кашмири представляется вероятной, степень этой близости, а также характер расхождений все еще требует выяснения.

Существенные трудности при решении данной проблемы создает недостаток данных. Объем материала по диалектам погули и каштавари не превышает таковой по сираджи и рамбани. Интересно отметить, что описывали все четыре диалекта главным образом одни и те же исследователи. Первые краткие описания каштавари и погули были сделаны Т. Г. Бейли [Bailey 1903: 51-60, 61-69]. На них во многом базируются разделы, посвященные этим диалектам в VIII томе «Дингвистического обзора Индии» [Grierson 19192: 342-401, 402432]. Наиболее подробный грамматический очерк погули написан П. К. Коулем и опубликован в тех же изданиях, что и очерк сираджи [Koul 19772; 20062]. Кроме того, списки слов 
каштавари и погули приводятся в неоднократно цитировавшейся выше статье [Schmidt, Kaul 2008]. Суммарный объем данных, содержащийся во всех этих источниках, неодинаков для двух рассматриваемых диалектов: для погули он значительно больше, чем для каштавари. Изменить эту ситуацию в будущем сможет только проведение широкомасштабных полевых исследований в долине Каштавар. Пока же следует быть готовым к тому, что крайне скудный материал каштавари может не позволить прийти к окончательным выводам относительно отношений этого диалекта со стандартным кашмири, и нам придется довольствоваться лишь более или менее вероятными гипотезами на этот счет.

\section{1. О происхождении звонкой придыхательной серии в диалектах погуяи и каштавари.}

Одной из характерных особенностей, отличающих диалекты погули и каштавари от стандартного кашмири, является наличие звонких придыхательных согласных. Они отмечаются как в ранних записях, в частности, у Т. Г. Бейли, так и в относительно новых, например, у П. К. Коуля. Интересно, что в каштавари уже в XX веке консонантная система, по-видимому, претерпела перестройку, аналогичную той, что имела место в соседних индоарийских языках - панджаби, догри и ряде языков группы пахари. Как следует из данных, опубликованных в работе [Schmidt, Kaul 2008], эта перестройка привела к утрате оппозиции по придыхательности у звонких взрывных. Звонкие аспираты перешли в глухие непридыхательные в начальной позиции и в простые звонкие во всех остальных. При этом возникла система тоновых оппозиций. Детали этого процесса, однако, остаются неясными ввиду скудости материала, который сводится фактически лишь к нескольким словам, зафиксированным в вышеуказанной статье. Поэтому в дальнейшем мы будем рассматривать главным образом материал каштавари из работ Т. Г. Бейли и Дж. Грирсона, в котором отражен консонантизм начала XX века с противопоставлением простых звонких и звонких придыхательных ${ }^{41}$.

Вопрос о происхождении звонкой придыхательной серии в погули и каштавари чрезвычайно интересен, особенно если принять во внимание вероятную близость обоих диалектов к кашмири, а, следовательно, принадлежность их к дардской группе. Г. Моргенстьерне считал звонкие придыхательные в каштавари архаизмом и приводил факт их наличия в качестве контраргумента против утверждения Дж. Грирсона о совпадении двух древних серий во всех дардских языках [Morgenstierne 1930: 297]. Нам же ситуация в рассматриваемых диалектах представляется неясной и требующей изучения, поскольку как для каштавари, так и для погули нельзя исключить вторичного развития звонких аспират по сценарию, сходному с кохистанским или восточнобелуджским. Поэтому мы

\footnotetext{
${ }^{41}$ Крайний недостаток данных не позволяет привести списка минимальных пар на простые звонкие и звонкие придыхательные. Поэтому вопрос о фонологичности их противопоставления пока не следует считать окончательно решенным. Тем не менее представляется показательным тот факт, что согласные обеих серий могут выступать в одних и тех же позициях в слове, например, в начальной и интервокальной (примеры см. ниже). Небезынтересны также такие пары (пусть и не являющиеся минимальными в строгом смысле слова), как dhār 'гора, холм' - dānd ‘бык', mhālu 'отец' - māl ‘имущество', bhāyu 'брат’ - bāh 'садись!', gharō ‘дом’ - gariñ 'жена'. Полностью аналогичной представляется и ситуация в диалекте погули. Здесь также обнаруживаются отдельные «нестрогие» минимальные пары: dānt ‘бык' - dhāv 'теки', balti 'вращающийся’ - bharti 'наполняющий'. Таким образом, фонологический характер оппозиции звонких по признаку придыхательности в обоих рассматриваемых диалектах представляется если не строго доказанным, то, по крайней мере, весьма вероятным.
} 
считаем необходимым рассмотреть материал обоих диалектов аналогично тому, как это было сделано для рамбани и сираджи (см. выше).

Первое, что обращает на себя внимание - специфика генетических связей лексем, содержащих звонкие придыхательные. Почти все они обнаруживают этимологические соответствия с тождественной семантикой в новоиндийских языках (в том числе распространенных в западногималайском ареале по соседству с погули и каштавари), а также в дардских языках, для которых представляется вероятным (или даже доказанным) существенное индоарийское влияние, но не обнаруживают параллелей в тех языках дардской группы, которые не подверглись такому влиянию. Это можно проследить на следующих примерах: кашт., пог. bhar- 'наполнять' при др.-инд. bharita- 'полный, накормленный', пали bharita- 'наполненный', хинди, пандж., лахнда, синдхи, зап. пах. (бхалеси), кумауни, неп., ория, гудж., мар. bhar- 'наполнять', кашм. bar- то же ${ }^{42}$; кашт. bhain 'сестра' при др.инд., пали bhaginī, пракр. bha(g)in̄i, bahinī, хинди bahin, пандж. bhain, лахнда, синдхи bhen, зап. пах. (бхадарвахи, чамеали) baihn, (бхалеси) bhen 'сестра', (пангвали) bhain 'младшая сестра', бенг. bain, ория bhaen̄i, гудж. bahen, мар. bahīn 'сестра', неп. baini 'младшая сестра',

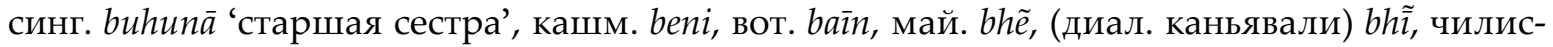

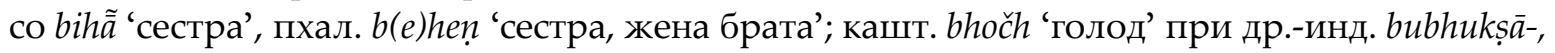

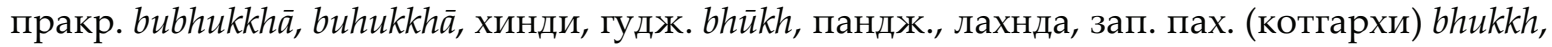
синдхи bhukha, неп. bhokh, бенг. bhukh, ория bhuk(h)a, мар. bhūk 'голод', кашм. bəčhi, май. bučh, торв. buš то же; кашт dhām 'пир' при др.-инд. dhārma- 'относящийся к дхарме, справедливому порядку', пандж. dhāmmā 'большой пир, приглашение брахмана на пир', зап. пах. (пангвали, джаунсари) dhām 'пир' [Turner 1966: 389]; кашт. krūdhī 'рассерженный' при др.-инд. krodhin-, хинди krodhī, пандж. karodhī то же; кашт. dhā̄i 'два с половиной’ при др.-инд. ardhatrtīya-, пали aḍ̣̂atiya-, пракр. aḍ̣häiya-, хинди, пандж., зап. пах. (бхадарвахи,

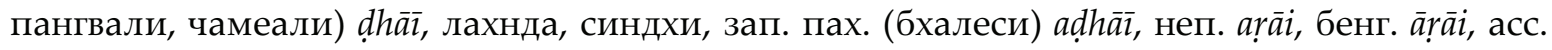
$\bar{a} r a i$, ория $a r h \bar{a} i$, гудж. $a d h \bar{i}$, кашм. d̦āy то же; кашт. ghar $(\bar{o})$, пог. ghar 'дом’ при пали, пракр., ория ghara-, хинди, пандж., лахнда, зап. пах. (бхадарвахи, бхалеси, кхашали), неп., асс., бенг. гудж., мар. ghar, синдхи gharu, синг. gara, кашм. gar - то же; кашт. gharī 'час' при др.инд. ghațī- 'часы; промежуток времени в 24 минуты', пракр. ghadī- 'часы', хинди 'часы; час; момент', пандж. gharī 'часы; момент; промежуток времени в 24 минуты', неп. ghari 'час, время', кашм. gər 'часы', шина garī 'гонг, часы, час'43; кашт. ghuru, пог. ghōru 'лошадь' при др.-инд. ghoța(ka)-, пали ghoțaka-, пракр. ghoda-, хинди, пандж., лахнда ghorā, синдхи, зап. пах. ghoro, бенг. ghõrā, асс. ghõrā, гудж. ghoro, мар. ghod̄a, кашм. gur, пхал. ghūru, сави ghuro, гауро, чилиссо gho, май., торв. ghō, башк. gor, вот. gōr, кал. (уртсунский диал.) ghōra, г.-б. guṛo, шум. gōọo, нинг. guro, паш. gọ̄ā то жен4; пог. ghraț 'мельница' при пракр.

42 В данной серии примеров индоарийские соответствия приводятся из наиболее крупных языков, а также из языков, ареально близких рассматриваемым диалектам. Дардские же параллели приводятся полностью. Отсутствие в настоящем списке параллели из какого-либо языка дардской группы означает, что в этом языке такая параллель не засвидетельствована. В случае с корнем bhar-, например, этимологическое соответствие отмечено лишь в одном дардском языке - кашмири.

43 Пример из шина считается индоарийским заимствованием [Turner 1966, 237]. Др.-инд. ghați- этимологически родственно др.-инд. ghaț- 'горшок'. Последнее слово имеет соответствия в ряде дардских языков: кхов. goḷ ‘кувшин', шина găi ‘глиняный горшок'. Однако эти слова семантически весьма далеки от приведенного примера из каштавари.

${ }^{44}$ Слово считается дравидийским по происхождению. Примечательно, что оно не засвидетельствовано в таких относительно свободных от индоарийского влияния дардских языках, как шина и кховар. Заслуживает внимание и его отсутствие в северных диалектах калаша, где сохраняется древнее индоевропейское название лошади (haš < *aśwa-). 
gharațta- то же, пандж. gharāt, зап. пах. (бхалеси, кхашали) ghrāț, неп. ghațta 'водяная мельница', лахнда ghuraț 'ручная мельница', кашм. grați 'водяная мельница', паш. garāt 'ручная мельница'45 ; пог. jhel- 'терпеть' при хинди, неп. jhel- 'страдать, переносить, претерпевать'.

Отдельные примеры слов со звонкими придыхательными имеют этимологические соответствия как в новоиндийских, так и в дардских языках, но при этом обнаруживают историко-фонетическое развитие, характерное для первых (ср. пог. йbha 'вверх' при др.инд. ürdhva- 'вертикальный, находящийся наверху', пандж. йbh 'вверх', лахнда (диал. аванкари) $u b b h \bar{a}$ 'верхний', зап. пах. (котгархи) hubbhi 'вверх, сверху', кумауни ubh 'высокий', ublã 'вверх', неп. и̃bho 'высокий, находящийся наверху', паш. (диал. лауровани) uḍäi, пхал. hund 'вверх, сверху', кашм. wod 'верхняя часть головы, черепная коробка'46). Нельзя не признать, что вероятность иноязычного (индоарийского) происхождения для таких слов довольно высока.

Наконец, еще одну группу составляют лексемы с фонетически близкими этимологическими параллелями и в дардских, и в индоарийских языках ареала (ср. кашт. bhāyu, bhōy ‘брат’ при др.-инд. bhrātar-, хинди, догри bhāi, пандж. bh(r)ā, зап. пах. (котгархи) bhai,

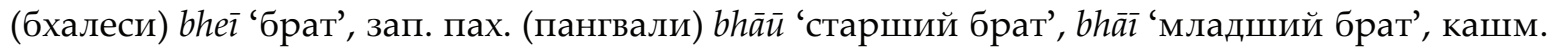
bōy, торв. bhā, г.-б. blāya, кал. bāya 'брат'; кашт. *dhūm (“tüm” [Schmidt, Kaul 2008, 288])

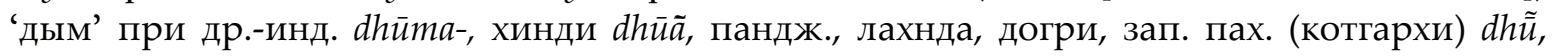
сир. *dhüm (“dúm”" [Schmidt, Kaul 2008: 288]), шина, вот. нинг. dum, паш., шум. dùm, кал. dhūm, пхал. dhūmī, башк. dìmī то же; кашт. bhumil ("pǔmil” [Schmidt, Kaul 2008: 292]) 'землетрясение’ при лахнда (диал. аванкари) bham, догри bhücal, bhumcal, кашм. bun'ul, торв. būmel, башк. bumäl, шина bũyāl то же; кашт. ghāsì (“kăsì” [Schmidt, Kaul 2008: 295]) 'трава' при др.-инд. ghāsa- 'пища; трава на пастбище', хинди, гархвали, зап. пах. (бхалеси) ghās, пандж., лахнда ghāh, догри $g h \bar{a}$, зап. пах. (котгархи) ghás, кашм. gāsi, паш., тир. gās, шум., г.-б. gãas, башк., торв. gā 'трава'; пог. dhav-, dhaũtul- 'бежать' при др.-инд. dhavate 'бежит', dhāvati 'бежит, течет', хинди dhā(v)-, пандж. dhāu-, зап. пах. (кхашали) dhabr- 'бежать, устремляться', кашм., паш. (диал. гульбахари) daw- 'бежать'"77; кашт. dhār 'холм' при зап. пах. (бхадарвахи, бхалеси) dhār 'холм', догри $d h \bar{a} r$ 'горный хребет', неп. dhār 'утес', паш., шум., нинг., г.-б., вот. $d \bar{a} r$ 'гора'; кашт. dārhi 'борода' при хинди, пандж., лахнда, догри dārh $\bar{\imath}$, кумауни, зап. пах. (бхадарвахи, бхалеси, кхашали) dāṝ, зап. пах. (котгархи) dáṛhi, неп. dāri, кашм. dār, торв. dáī, башк. dèr, шина dã̄i, тир., паш, шум., г.-б. dārī то же). Строго говоря, для подобного рода примеров нельзя исключать а priori принадлежность ни к исконной, ни к заимствованной лексике. Следует также допустить возможность контаминации дардского слова с индоарийским и появление придыхания в первом под влиянием последнего. Подобное явление было отмечено нами в дардских языках кохистанской подгруппы [Коган 2008].

Выше рассмотрены практически все случаи звонких придыхательных в каштавари и погули ${ }^{48}$. Не будет преувеличением сказать, что ни в одном из диалектов не удалось об-

45 Пример из пашаи считается индоарийским заимствованием [Morgenstierne 1956: 73; Turner 1966: 240].

46 Показательно, что в данном случае погули обнаруживает явное историко-фонетическое расхождение и с кашмири - языком, предположительно наиболее близком к нему генетически.

${ }^{47} \mathrm{C}$ тем же общеарийским прототипом, несомненно, связано и пог. dhāv- 'течь'. На достаточно высокую вероятность иноязычного происхождения этого глагола указывает тот факт, что его основа в погули продолжает древнюю основу с долгим $\bar{a}$, широко распространенную в индоарийских языках, но не отмеченную в дардских. Нельзя исключить, что близкие по семантике глаголы ‘течь' и ‘бежать' контаминировали внутри самого диалекта погули, результатом чего и явилось появление вторичного придыхания в исконном глаголе dhav-.

${ }^{48}$ Отмечены также отдельные примеры звонких аспират в словах без надежной этимологии (ср. пог. dhaũ- 'ходить, гулять', пог. dhora 'скала'). В каштавари кроме того имеются придыхательные $m h$ и пh (ср. 
наружить ни одного сколько-нибудь надежного примера сохранения древней звонкой аспираты в исконном слове. Данная ситуация представляется аналогичной той, что была выявлена нами в языках торвали и майян [ibid.]. Там она, как уже говорилось, объясняется вторичным характером звонких придыхательных согласных, в пользу чего свидетельствует, в частности, наличие примеров дезаспирации, не объяснимой ни заимствованием, ни особой позицией в слове. Подобные примеры имеются и в диалектах каштавари и погули (ср. пог. baz- 'ломать' при др.-инд. bhajyate 'ломается', bhanakti 'ломает', bhañjanti 'ломают'; пог. bāl- 'смотреть, видеть' при др.-инд. bhālayati 'замечает', пандж., лахнда bhāl- 'искать', зап. пах. bhāl- ‘держать в поле зрения’, гудж. bhāl- ‘наблюдать'; пог. bopturi 'племянник (сын брата)' при др.-инд. bhrātrputra- то же; пог. dūm 'дым' при др.инд. dhūma- то же; пог. dod 'молоко' при др.-инд. dugdha-, лахнда, пандж. duddh, хинди $d \bar{u} d h$ то же; пог. gās 'трава' при др.-инд. ghāsa- 'пища; трава на пастбище'49; пог. giu 'топленое масло' при др.-инд. ghrta-, хинди, зап. пах. (бхадарвахи) ghi, пандж. gheu, лахнда ghiū, неп. ghiu то же; кашт., пог. manz 'в', пог. manzamu 'средний' при др.-инд. таdhyama-

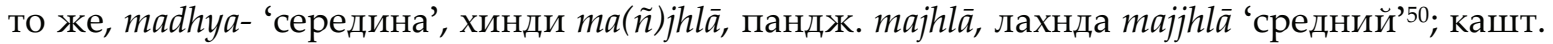
abar 'облако' при др.-инд. abhra- 'облако, туча; дождливая погода'; кашт. badāw- 'увеличивать’ при др.-инд. vardhāpayati ‘увеличивает', хинди badhā-, пандж. vadhāu-, лахнда vadhāv'увеличивать'; кашт. daz- 'гореть' при кашм. daz-, пхал., сави daj-, шина daž- то же, торв. daž- 'жечь' из общедард. *daj-, общеар. *dajh- ‘жечь, гореть' > др.-инд. dahati ‘жжет’).

Приведенные примеры дают все основания полагать, что как в погули, так и в каштавари имело место совпадение звонкой придыхательной серии со звонкой непридыхательной. Однако детали этого процесса в некоторых случаях все еще остаются непроясненными. Более или менее ясной представляется ситуация в погули. Здесь дезаспирация обнаруживается в различных позициях в слове, и, таким образом, ее наличие не может быть объяснено особенностями фонетического окружения. Не представляется возможным связать ее и с иноязычным влиянием. Хотя погули и находится (и, возможно, находился в прошлом) в контакте со стандартным кашмири, утратившим противопоставление двух древних серий звонких, этого обстоятельства недостаточно для объяснения отсутствия придыхания во всех приведенных выше словах: некоторые из них - baz- 'ломать', bāl- 'смотреть, видеть', bopturi 'племянник' - не имеют в стандартном кашмири никаких соответствий ${ }^{51}$, а у одного - dūm 'дым’ - кашмирская этимологическая параллель (dih 'дым') далеко отстоит фонетически и восходит к другому древнему суффиксальному образованию. Заслуживает внимания также и тот факт, что среди примеров из погули имеются слова, относящиеся к редко заимствуемой базисной лексике, в частности, два слова стословного списка М. Сводеша - bāl- ‘смотреть, видеть' и dūm 'дым'

Рефлексация древних звонких придыхательных в каштавари все еще не вполне ясна, причиной чего, возможно является недостаток материала. Ни одного случая дезаспирации в начале слова обнаружить не удалось. В двух из трех приведенных выше примеров - manz 'в' и abar 'облако' - общеарийская аспирата выступала в преконсонантной

mhālu 'отец', nhōri 'снова'), отсутствовавшие в общеарийском. Позднее происхождение этих согласных не вызывает сомнения.

49 Остальные параллели см. выше.

50 Совмещение значений ‘середина' и 'в’ у рефлексов общеарийск. *madhya- характерно для стандартного кашмири, где та и другая семантика присутствует у слова manz.

${ }^{51} \mathrm{~K}$ этим трем примерам, возможно, примыкает еще один - bī- ‘бояться’ (ср. др.-инд. bhīyate, bibheti ‘боится’). Однако поскольку остается неясным, какая древняя основа (редуплицированная или нередуплицированная) отразилась в диалекте погули, вопрос о дезаспирации древнего придыхательного в данном глаголе следует считать открытым. 
позиции, благоприятной для потери придыхания. Кроме того, ни для одного из этих примеров нельзя исключить заимствование (ср. кашм. manz 'в'; кашм. obur, перс. abr 'облако’ ${ }^{52}$. Примера дезаспирации в предвокальном положении в нашем распоряжении два: badāw- 'увеличивать' и daz- 'гореть', что недостаточно для того, чтобы делать окончательные выводы. С уверенностью можно сказать лишь то, что исчезновение древней аспирации нельзя считать позиционным развитием, характерным для середины слова, поскольку в каштавари отмечены примеры срединных звонких аспират ( $k r \bar{u} d h \bar{\imath}$ 'рассерженный’, dārhi ‘борода').

Помимо приведенных выше, небезынтересным примером является кашт. gand- 'связывать, завязывать' < *granth- (ср. др.-инд. granthayati 'связывает'). В нем старый глухой придыхательный th в позиции озвончения отразился в виде простого звонкого d. Если предположить, что древняя звонкая придыхательная серия сохранилась в каштавари, такое развитие представляется труднообъяснимым. Скорее следовало бы ожидать появление звонкой аспираты, как в соседних новоиндийских языках (ср. пандж., лахнда, зап. пах. (чамеали) gandh-). В случае же, если мы признаем, что в рассматриваемом диалекте звонкие аспираты до определенного исторического момента отсутствовали, утрату придыхания при озвончении глухого th следует считать вполне закономерной. Датировать ее, разумеется, следует эпохой, предшествуюей усвоению индоарийских заимствований со звонкими придыхательными согласными.

Таким образом, если для погули совпадение древней звонкой придыхательной серии со звонкой и вторичный характер современных звонких аспират представляется доказанным, то для каштавари такая картина может быть принята лишь в качестве вероятной гипотезы, требующей дальнейшей проверки. Такая проверка станет возможной лишь в случае существенного пополнения доступного языкового материала.

\section{2. Кашмирское передвижение сибидянтов и аффрикат и диалект погуди.}

В кратком описании погули в “Linguistic Survey of India” Дж. Грирсон указывает отдельные случаи сохранения в этом диалекте древнего сибилянта ś, перешедшего в стандартном кашмири в ларингальный $h$ : šāput 'медведь' при кашм. hāput то же, др.-инд. śvāpada- 'дикий зверь'; šō ‘как, в качестве' при кашм. h’uh (м. p.), hiš (ж. р.) 'как, подобно'53 [Grierson 19192: 404]. К этим двум примерам можно добавить еще три: šahur 'свекор' при кашм. hihur, др.-инд. śvaśura-; šah ‘свекровь' при кашм. haš, др.-инд. śvaśrū-; šāwal- ‘показывать’ при кашм. hāw- ‘объяснять, показывать', др.-инд. śrāvayati ‘провозглашает'54. Приведенный материал представляется весьма интересным, поскольку имеет непосредственное отношение к проблеме генетических отношений погули и стандартного кашмири.

52 Следует, впрочем, отметить, что более вероятным для обоих слов представляется незаимствованное происхождение, причем не только в силу их базисного характера. Название облака в каштавари не обнаруживает следов $u$-умлаута, характерного для современного стандартного кашмири. Нет в нем и конечного огубленного гласного, вызывавшего развитие умлаута, что делает маловероятным заимствование более архаичной кашмирской формы. Проникновение слова из персидского хотя и не исключено, но все же менее вероятно, чем принадлежность к исконному пласту: во многих языках ареала отмечены рефлексы общеарийск. *abhra- с несомненно исконным историко-фонетическим развитием (ср. шина, май. аžu, чилиссо ažo, г.-б. albeno, паш. ōbra), но нет ни одного несомненного примера заимствования обозначения облака из персидского.

53 Возможно, родственно др.-инд. ìdrśa- 'такой’ [Turner 1966: 73].

${ }^{54}$ Ср. аналогичное семантическое развитие в пушту: șāy- 'показывать' < *śrāvaya-. 
Одной из ярких черт исторической фонетики последнего являются переходы *ś $>h$ и *šs > š, названные нами передвижением сибилянтов ${ }^{55}$. От ответа на вопрос о наличии или отсутствии подобных переходов в погули, разумеется, напрямую зависит относительная датировка его расхождения с диалектами Кашмирской долины.

Решение данной проблемы осложняется наличием в погули целого ряда несомненных примеров развития *ś > h: hun 'собака' при др.-инд. śvan- / śun-, кашм. hūn то же; hing 'рог’ при др.-инд. śrnga-, кашм. heng то же; hat '100' при др.-инд. śatam, кашм. hath то же; hun- 'слышать' при др.-инд. śrnoti 'слышит'; dah '10' при др.-инд. daśa, кашм. dah то же; wih '20' при др.-инд. viṃśati, кашм. wuh то же. Переход сибилянта в ларингал в этих примерах едва ли может быть объяснен позицией в слове. Нельзя считать удовлетворительным объяснением и заимствование из стандартного кашмири, поскольку в последнем некоторые из указанных здесь примеров (hun- 'слышать') не обнаруживают этимологических параллелей, а кроме того, все вышеприведенные слова относятся к базисной лексике (три из них - hun 'собака', hing 'рог' и hun- 'слышать') входят в стословный список М. Сводеша ${ }^{56}$.

С другой стороны, ни один из примеров сохранения старого сибилянта нельзя считать надежным. Начальный š в слове šah ‘свекровь' мог возникнуть в результате метатезы. Иными словами, вполне возможным представляется развитие šah < *haš (ср. кашм. haš), где конечный $\check{s}$ закономерно развился из древней группы śr через промежуточную ступень в виде церебрального ${ }^{5}{ }^{57}$. По аналогии с данным словом начальный сибилянт мог возникнуть в обозначении свекра (šahur). В глаголе šāwal- 'показывать' сибилянт следует считать регулярным, поскольку его прототипом является не одиночный ś, а кластер śr. Незакономерен в данном случае начальный $h$ в стандартном кашмири. Не исключено, что он развился по аналогии с утраченным в современном языке рефлексом древней основы *śrn- 'слышать' с регулярным начальным $h$ (ср. погули $h u n-$ ). Такой процесс аналогического выравнивания представляется вполне вероятным, поскольку современный кашмирский глагол $h \bar{a} w$ - продолжает именно древний каузатив от глагола 'слышать' и до сих пор совмещает значения 'показывать' и 'объяснять'. Древний прототип начального сибилянта в пог. šō 'как, в качестве' неясен, поскольку неясна этимология этого слова. Предложенное Дж. Грирсоном сопоставление с кашм. h'uh следует признать спорным, поскольку этапы историко-фонетического развития остаются непроясненными. Не представляется бесспорным и сопоставление пог. šāput с др.-инд. śvāpada'дикий зверь'. Соответствия между этими формами нерегулярны, причем это касается не только начального согласного: интервокальный $p$ должен был отразиться в погули (а также и в стандартном кашмири) в виде $w$, а интервокальный $d-$ выпасть. Поэтому этимологию Дж. Грирсона не следует принимать безоговорочно. Происхождение названия медведя в кашмирских диалектах все еще остается неясным. Следует иметь в виду, что речь идет об обозначении хищного животного, название которого нередко табуируется и, как следствие этого факта, подвергается нерегулярным фонетическим изменениям.

Таким образом, нет никаких веских оснований говорить о большей архаичности сибилянтной системы погули по сравнению с кашмирской. Как позволяет судить имеющийся языковой материал, кашмирское передвижение сибилянтов затронуло и этот диалект. Единственное существенное расхождение заключается в наличии в погули пе-

\footnotetext{
55 Подробнее об этом явлении см. [Коган 2009 $]$.

56 Показательно, что среди примеров сохранившегося сибилянта таких слов нет.

${ }^{57}$ Об этом историко-фонетическом процессе в кашмири см. [Коган 20092].
} 
рехода *气̣̆ $>h^{58}$ в конечной позиции (ср. nuh 'сноха' при др.-инд. snușā, кашм. nəš; pyuh 'блоха' при др.-инд. pluși-, кашм. p'uš). По всей видимости, речь в данном случае идет об ауслаутном ослаблении сибилянта. Диалекты Кашмирской долины, где подобное явление отсутствует ${ }^{59}$, несомненно, сохраняют в данном случае более архаичное состояние, нежели диалект погули.

Развитие в погули древних среднеязычных аффрикат, по-видимому, совпадает с кашмирским, то есть имеет место их передвижение в зубной ряд (ср. cāur '4' при др.-инд.

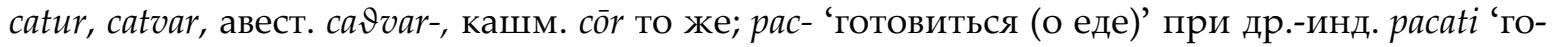
товит пищу', pacyate 'готовится, переваривается (о пище), зреет', авест. pacata 'готовится (о пище)', кашм. pācakh 'удобоваримый (о пище)'; baz- 'ломать' при др.-инд. bhajyate ‘ломается’ < индоир. *bhang/y- [EWA II, 242]). Как и в стандартном кашмири, в данном диалекте обнаруживаются следы наличия в прошлом церебральных аффрикат ${ }^{60}$ (ср. $\check{c}<t$ в lŏkhčyӗ 'маленький, младший (косв. пад. ед. ч.)' при кашм. lŏkuț то же (прям. пад. ед. ч.)). Таким образом, есть все основания предполагать наличие в погули «кашмирского передвижения аффрикат». Вместе с тем аффриката с̌ в погули в ряде случаев возникает в результате историко-фонетического процесса, не характерного для стандартного кашмири: ее источником может служить древняя группа *tr (ср. с̌āi '3' при др.-инд. trayah, кашм. trĕ; pečow 'дядя (брат отца)' при кашм. pĕtir то же, др.-инд. pitriya- 'отцовский'). Учитывая, что современный палатальный с может возникать из более старого церебрального с̆, можно предположить наличие в раннем погули перехода $t r>\check{c}$. Аналогичное явление, как известно, присуще ряду других дардских языков: шина и части кохистанских. Нельзя, впрочем, исключить и иной сценарий развития: переход группы $t r$ непосредственно в $\check{c}$ (в результате оглушения $r$ и его перехода в $\check{s}$ ?) после передвижения аффрикат. Предпочесть какую-либо из гипотез при современном уровне знаний не представляется возможным.

\section{Придожение \\ Стословный список диалекта сираджи}

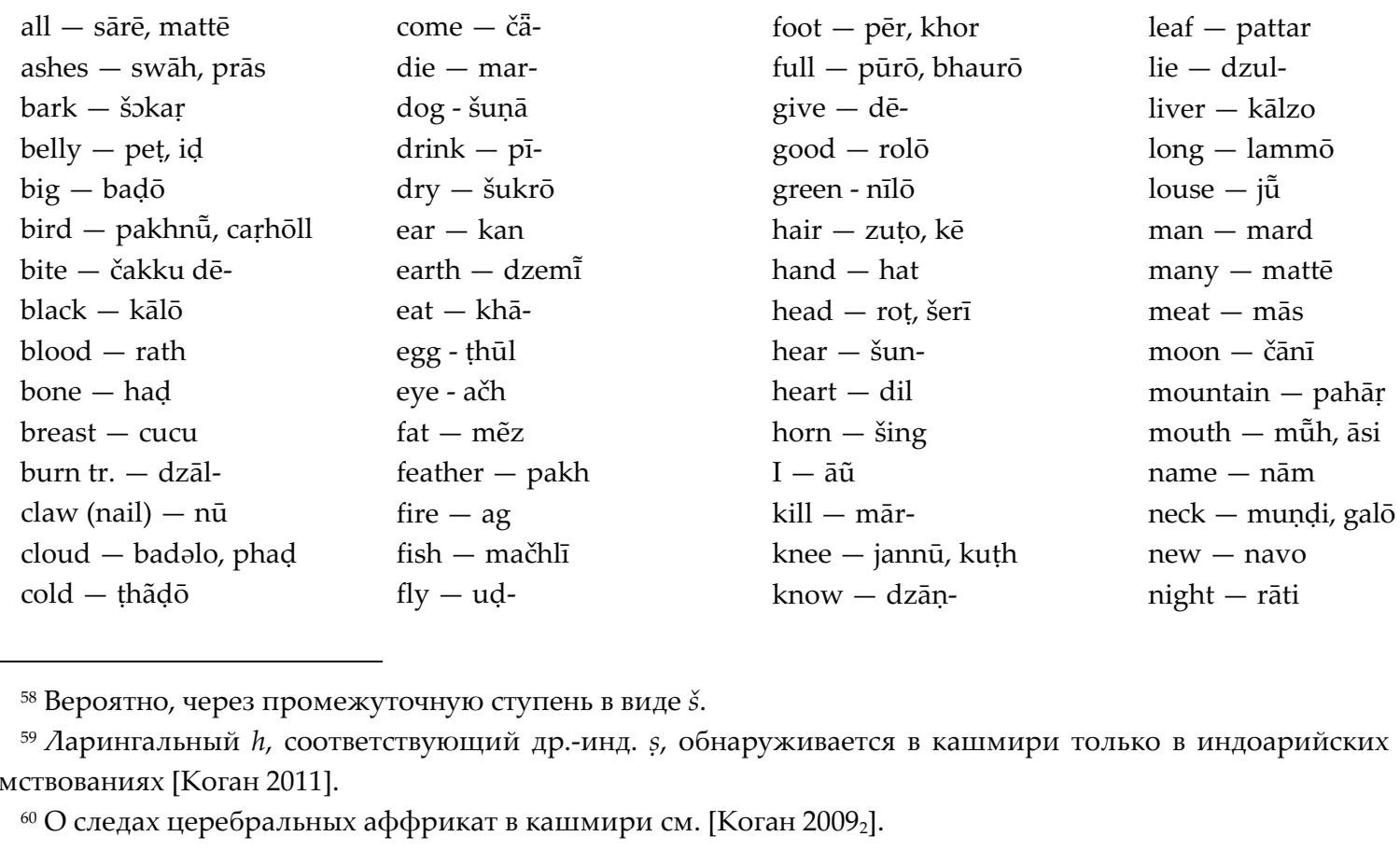




\begin{tabular}{|c|c|c|c|}
\hline nose - nak & say - dz̄̄- & stone - ghōrr & two - dui \\
\hline not - na & see - her- & sun - dīs & walk (go) - gā- \\
\hline one - ekk & seed - bij & swim - tar- & warm - tattō \\
\hline person - māṇũ & sit - biš- & tail - lengan & water - pāṇi \\
\hline rain - dēō & skin - niyāli & that $-\mathrm{su}$, ung & we - āh \\
\hline red - lāl, rattṛō & sleep - dzul- & this - yō & what - kō \\
\hline road - batt & small - nikṛo & thou - tu & white - chittō \\
\hline root $-\mathrm{dz} \overline{1} l$ & smoke - dúm & tongue $-\mathrm{zib}$ & who - kē \\
\hline round - gōl & stand - kharōoṭh- & tooth - dant & woman - zenān \\
\hline sand - rēt & star - tārō & tree - buțə & yellow - haldro \\
\hline
\end{tabular}

\section{Сокращения}

$\begin{array}{ll}\text { авест. - авестийский } & \text { неп. - непали } \\ \text { асс. - ассамский } & \text { нинг. - нингалами } \\ \text { башк. - башкарик } & \text { общеар., общеарийск. - общеарийский } \\ \text { бенг. - бенгали } & \text { общедард. - общедардский } \\ \text { вот. - вотапури } & \text { осет. - осетинский } \\ \text { г.-б. - гавар-бати } & \text { пандж. - панджаби } \\ \text { гудж. - гуджарати } & \text { паш. - пашаи } \\ \text { др.-инд. - древнеиндийский } & \text { пог. - погули } \\ \text { др.-иран. - древнеиранские диалекты } & \text { пракр. - пракриты } \\ \text { зап. пах. - языки западной подгруппы груп- } & \text { пхал. - пхалура } \\ \quad \text { пы пахари } & \text { рам. - рамбани } \\ \text { ишк. - ишкашимский } & \text { синг. - сингальский } \\ \text { кал. - калаша } & \text { сир. - сираджи } \\ \text { кашм. - кашмири } & \text { согд. - согдийский } \\ \text { кашт. - каштавари } & \text { тир. - тирахи } \\ \text { кл.-перс. - классический персидский } & \text { торв. - торвали } \\ \text { кхов. - кховар } & \text { шугн. - шугнанский } \\ \text { май. - майян } & \text { шум. - шумашти } \\ \text { мар. - маратхи } & \end{array}$

\section{Питература}

Коган 2005 - А. И. КОГАН. Дардские языки. Генетическая характеристика. М., Восточная литература, 2005. [A. I. KogAn. Dardskie yazyki. Geneticheskaya harakteristika. M., Vostochnaya literatura, 2005.]

Коган 2008 - А. И. КОГАН. О статусе и происхождении звонкой придыхательной серии в ряде дардских языков // Indologica. Памяти Т. Я. Елизаренковой. Книга 1. Orientalia et Classica. Вып. 20. М., РГГУ, 2008. C. 197-225. [A. I. KOGAN. O statuse i proishozhdenii zvonkoi pridyhatel'noi serii v ryade dardskih yazykov // Indologica. Pamyati T. Ya. Elizarenkovoi. Kniga 1. Orientalia et Classica. Vyp. 20. M., RGGU, 2008. S. 197-225.]

Коган 2009, - А. И. КОГАН. Кашмири // Большая российская эни̨иклопедия. Т. 13. М., 2009. [A. I. KоGAN. Kashmiri // Bol'shaya rossiiskaya enciklopediya. T. 13. M., 2009.]

Коган $2009_{2}$ - А. И. КОГАН. К вопросу о ряде фонетических изменений в языке кашмири и их относительной датировке // Аспекты компаративистики 4. М., РГГУ, 2009. С. 25-54. [A. I. KOGAN. K voprosu o ryade foneticheskih izmenenii v yazyke kashmiri i ih otnositel'noi datirovke // Aspects of comparative linguistics 4. M., RGGU, 2009. S. 25-54.]

Коган 2011 - А. И. КОГАН. К характеристике индоарийских элементов в языке кашмири // Вопросы языкового родства, №5, 2011, с. 23-47. [A. I. KOGAN. K harakteristike indoariiskih elementov v yazyke kashmiri // Journal of Language Relationship, №5, 2011, s. 23-47.] 
Старостин 1989 - С. А. СТАРОстиН. Сравнительно-историческое языкознание и лексикостатистика // Иингвистическая реконструкция и древнейшая история Востока. Материалы к дискуссиял на Международной конференциии (Москва, 29 мая - 2 июня 1989 г.). М., 1989. [S. A. STAROSTIN. Sravnitel'no-istoricheskoe yazykoznanie i leksikostatistika // Lingvisticheskaya rekonstrukciya i drevneishaya istoriya Vostoka. Materialy $k$ diskussiyam na Mezhdunarodnoi konferencii (Moskva, 29 maya - 2 iyunya 1989 g.). M., 1989.]

Bailey 1903 - Studies in Northern Himalayan Dialects by Rev. T. Grahame BAILEY. Calcutta, Baptist Mission Press, 1903.

Bailey 1908 - The Languages of the Northern Himalayas, Being Studies in the Grammar of Twenty-six Himalayan Dialects by Rev. T. Grahame BAILEY. London, 1908.

Edelman 1983 - D. I. EDELMAN. The Dardic and Nuristani languages. M., 1983.

Grierson 1919 - G. A. GRIERSON. Linguistic Survey of India. Vol. VIII, pt. 1: Indo-Aryan Family. North-Western Group. Specimens of Sindhi and Lahnda. Calcutta, 1919.

Grierson 1919, - G. A. Grierson. Linguistic Survey of India. Vol. VIII, pt. 2: Specimens of the Dardic or Piśāca Languages (including Kāshmīiñ). Calcutta, 1919.

Grierson 1929 - G. A. GRIERSON. Torwali, an Account of a Dardic Language of the Swat Kohistan. L., 1929.

EWA II - M. MAYRHOFER. Etymologisches Wörterbuch des Altindoarischen. II Band. Heidelberg, Universitätsverlag Carl Winter, 1996.

Hendriksen 1976-86 - H. HeNDrIKSEN. Himachali studies. Vol 1: Vocabulary. Vol. 2: Texts. Vol. 3: Grammar. København, $1976-86$.

Kaul 1995 - Omkar. N. Kaul. On Kashmiri Language // Kashmiri Pandits: A Cultural Heritage. Edited by Prof. S. Bhatt. New Delhi, Lancers Books, 1995.

Koul 1977 1 - P. K. Koul. Sirājī // Candrabhāgā tat kī parvatīya boliyã. Jammū, 1977.

Koul 1977 2 - P. K. Koul. Poglī // Candrabhāgā taț kī parvatīya boliyã. Jammū, 1977.

Koul 2006 1 - P. K. Koul. Sirājī // Pahari and Other Tribal Dialects of Jammu. Vol. II. Delhi, 2006. Pp. 318-350.

Koul $2006_{2}$ - P. K. Koul. Poglī // Pahari and Other Tribal Dialects of Jammu. Vol. II. Delhi, 2006. Pp. 378 -412.

Mock 2008 - J. Mock. Dards, Dardistan and Dardic: an Ethnographic, Geographic and Linguistic Conundrum //

Nigel J. R. Allan, ed. Northern Pakistan: Karakorum Conquered. New York, St. Martin's Press, 2008.

Morgenstierne 1930 - G. Morgenstierne. Notes on Torwali // Acta Orientalia, 8, 1930, pp. 294-310.

Morgenstierne 1956 - G. MorgenstiennE. Indo-Iranian Frontier Languages. Vol III: The Pashai Language. Pt. 3: Vocabulary. Oslo, 1956.

Schmidt 1981 - R. L. SchMidT. Report on a Survey of Dardic Dialects of Kashmir // Indian Linguistics, 42, 1981, pp. $17-21$.

Schmidt, Kaul 2008 - R. L. SCHMIDT, V. K. KAUL. A Comparative Analysis of Shina and Kashmiri Vocabularies // Acta Orientalia, 69, 2008, pp. 231-302.

Turner 1966 - R. L. TURnER. A Comparative Dictionary of the Indo-Aryan Languages. L., 1966.

Varma 1948 - S. VARMA. The Bhalesī Dialect. The Royal Asiatic Society of Bengal. Monograph Series. Vol. IV. Calcutta, 1948.

Warikoo 1996 - K. WARIKOO. Language and Politics in Jammu and Kashmir: Issues and Perspectives // Jammu, Kashmir and Ladakh: Linguistic Predicament. Edited by: P. N. Pushp and K. Warikoo. Delhi, 1996.

The article discusses the issue of genetic relationship between Literary Kashmiri and four dialects located outside the Vale of Kashmir. In the past, these dialects were frequently classified as representing the Kashmiri language, but specific arguments in favor of such a classification were usually unconvincing. The author concludes that two of these dialects (Siraji and Rambani) cannot be defined as either dialects of Kashmiri or even as Dardic languages, but should rather be classified with the Indo-Aryan group. At the same time, the other two dialects, Poguli and Kashtawari, actually do show close genetic affinity to Standard Kashmiri.

Keywords: Kashmiri, Dardic languages, Indo-Aryan languages, language classification, areal linguistics. 